\title{
Seaweeds Jobs Value-Chain Analysis in Zamboanga Peninsula, Philippines, 2015
}

\author{
Teresita A Narvaez* \\ Professor 6, Western Mindanao State University, Philippines \\ *Corresponding author: Teresita A Narvaez, Professor 6, Western Mindanao State \\ University, Zamboanga City, Philippines, Email: teresitanarvaez52@gmail.com
}

\section{Research Article \\ Volume 2 Issue 2}

Received Date: March 19, 2018

Published Date: April 24, 2018

\section{Abstract}

Seaweeds, an important commodity in the Zamboanga Peninsula region, provide income and employment to 175,000 marginalized coastal dwellers. This Job value chain study looks into the flight of the affected coastal farmers who are economically at the disadvantage; determine the job opportunities and practical recommendation to create more and better jobs in Mindanao. The full time job in the entire value chain were computed based on the survey and focus group discussion of seaweed farmers, barangay traders, consolidators, big traders and processor.

Seaweed farmers in Zamboanga Peninsula region cultivates an average of $1 / 4$ hectare with an average production of 5,646.5 kg per cropping. The computed average production cost is P 2.75 per kg of seaweeds sold at P5.00 per kg. Seaweed farming is a family-based enterprise with a total of 0.643 full time employments (FTE) per hectare.

The major constraints for creating more and better job includes: lack of good quality planting materials to increase productivity; lack of cheap and ready access credit for farmers; poor post- harvest facilities such as drying and storage resulting to low quality raw dried seaweeds; poor roads resulting to high overhead cost of farmers.

To create additional job in the seaweed industry, effort shall be geared toward establishment of seaweed gene bank and nurseries; conduct of research and development program on disease and climate change resistant varieties; development of food and non-food high-value added products from seaweeds through research; provision of financing windows for small and marginalized seaweed farmers; opportunity of crop assistance and insurance programs; establishment of a seaweed quality certification system; government assisted processing facilities particularly additional stilt dryers, moisture content detector and clean storage areas free from contaminations. Finally, establishments of social enterprises or cottage industries through inter -agency collaboration on value addition of seaweed products. 


\section{International Journal of Oceanography \& Aquaculture}

\section{Introduction}

\section{Background}

In The Philippines, Mindanao area contributes about 57 percent of the national seaweed production [1]. Zamboanga Peninsula ranks third of the top five producing regions, contributing 13 percent of seaweeds [2]. The varieties of seaweeds grown are Kappaphycus, Eucheuma and Glacilaria. The Kappaphycus and Eucheuma have high commercial value that produce kappa and iota (soft-gelling) carrageenan while Glacilaria is consumed for human food and feed for abalone [3]. Kappaphycus was originally known as Eucheuma cottonii that evolved into varied shapes, size and color, and now in red, green and brown varieties [4]. Farmers and traders called it 'cottonii'. Eucheuma is commonly called "spinosum". Cottonii has high carrageenan content compared to spinosum and thus priced 3 times higher in the market. For this reason about 80-90percent of the farmers cultivate kappaphycus. However, in some shallow waters Eucheuma thrives best and therefore, being cultivated by about 8 percent of the farmers while 2percent cultivates Glacilaria [4].

Seaweeds in Zamboanga Peninsula are one of the flagship and champion products identified by the Regional Development Council. It has a vast coastline stretching to $1,330 \mathrm{~km}$ or $27,814.90$ hectares of coastal waters planted to seaweed production and potential area of 17,151 hectares [5]. The industry provides income and employment to some 175,000 coastal and island dwelling households including those displaced workers and farmers caused by peace and order disturbances in nearby regions [6]. Likewise, it is also an important livelihood option of fishermen affected by the closed fishing season of sardines (Implementation of BFAR Administrative Circular 255) from December 1 to March 1 of every year [7]. The seaweed industry in Zamboanga Peninsula region involves 26,488 farmers, 148 domestic traders and 2 big processors [5].

\section{Objectives of the Study}

As an important commodity in the region, seaweeds industry was engaged by majority the marginal sectors. It is important to look into the flight of the affected farmers who are economically at the disadvantage; determine the job opportunities and practical recommendation to create more and better jobs in Mindanao Specifically, the study aims to:

1. Determine the number and type of jobs available under the current value-chain;
2. Identify constraints to expansion, and thus job creation; 3. Estimate the number and type of jobs that can be created if the constraints are addressed.

\section{Methodology}

The data collection was concentrated in the number one producing province in the region- Zamboanga Sibugay. Both secondary and primary data were collected. Triangulation method was used- key informant interviews (KIIs), survey and focus group discussion (FGD) of seaweed farmer, traders, consolidators and processor. Using the secondary data from the provincial agriculture office of the province of Zamboanga Sibugay, top 3 seaweed producing municipalities were identified: Alicia, Ipil and Tungawan. First visit of these municipalities was done to conduct the key informant interviews (KIIs) with the municipal agriculturist, field technicians, famers association's representatives and local traders to determine the status, policies and support provided to the seaweed industry. From each municipality three barangays were identified to be the source of the survey information. The barangay chosen were based on the following criteria: presence of numerous farmers farming a maximum of 4 cycles a year; famers who were able to plant in 2014; distance of the barangay in the municipal center; and peace and order condition. Five farmers were chosen from the list of seaweed farmers in the barangay taken from the office of the municipal agriculturist. Simple random sampling was employed and a total of 10 farmers per municipality were surveyed using the survey questionnaire prepared for this study. Traders, consolidators and processors were likewise interviewed. The result of the survey was further validated through FGD. These are participated by selected respondents who were interviewed during the survey. Trained enumerators hired were those already worked in previous studies. After the survey, focus group discussions were conducted in three municipalities to probe in some important information relevant to the study.

Three sets of questionnaires were formulated and validated for the survey- seaweeds farmers, traders / consolidators and processors of raw dried seaweeds. The information contained in the questionnaire for farm level includes: demographics, farm and farming related information, seaweed production data (2014-2015), product disposal and marketing outlets ( supply chain), farm jobs and activities, household income, cost and return analysis ( per hectare, per year), disease management, availability and access facilities, credit, 


\section{International Journal of Oceanography \& Aquaculture}

market and other support services, constraints to job creation in seaweed industry and recommendations to improve seaweed productivity. Almost similar information is found in the questionnaires for traders and processors, except for the detailed activities in the trading or processing.

The KIIs and FGD were conducted using several guide questions, more importantly on why the seaweed important for jobs in Mindanao and what is the direct and indirect impact on jobs and the constraints in attaining high productivity. The information contained in this report were taken from the 30 seaweed farmers of the province, 10 local traders, 4 big traders, one consolidator/ exporter of RDS, and one processor/ exporter of semirefined carrageenan.

Data were analyze using descriptive methods and job estimates were determine using prescribed formula by World Bank who funded the study. Full time work is defined in this study as work covering 8 hours a day, 5 days a week or 56 weeks a year or 312 days a year.

Job value chain mapping is color coded. Constraints were differentiated form each other using the following colors: red means severe constraints; orange means moderate constraints, yellow means minor constraints and green means no constraints while white means no information.

\section{Results and Discussion}

\section{Profile of Seaweed Industry in Zamboanga Sibugay}

Zamboanga Sibugay province is the leading producer of seaweeds in the region. It is cultivated in 11 coastal municipalities out of 16 municipalities with 113 organized farmers association and a total of 7,847 member-farmers. The total area planted to seaweeds is 20,220 has with 25,488 farmers and a potential area of 9,454 has in 2015. Production declined gradually from $126,428.85$ metric tons in 2011 to $91,473.98$ metric tons in 2014 approximately 28 percent or $34,954.87$ metric tons. The decline is caused by bad weather conditions and farmers were not able to maximize production of 3-4 cycles, poor farming practices, decrease in high breed vigor of seed stock, attacked of "ice-ice" disease and epiphytes.
Types of farming adopted by farmers in Zamboanga Sibugay are either near shore or deep sea farming. The choice of farmers on the type of farming depends on the nature of farming area such as movement of water, weather, shorelines and financial capability of farmers. The most common type of farming in the entire province is near shore because it is easy and cheaper, but susceptible to pathogenic infection such as "ice-ice", vulnerable to currents and waves and has lower yield. It has a distance of $0.50 \mathrm{~km}$ to $1.0 \mathrm{~km}$ from shoreline and a depth of 0.5 to 2.5 meters.

About 90 percent of the farmers are into near shore with an average of $1 / 4$ hectare per farmer. Deep sea farming is planted farther than $1.0 \mathrm{~km}$ and a depth of more than 2.5 meters. It is more expensive because of anchor bars as post for the entire farm. Other farmers who lack investment used bamboo post or mangrove as anchor for the plants. Likewise, it is labor intensive and time-consuming. It is resistance to pathogenic infection due to cooler temperature, resilient to strong waves and currents and produced higher yield.

\begin{tabular}{|c|c|c|}
\hline Province / City & $\begin{array}{c}\text { Area Planted } \\
\text { (has.) }\end{array}$ & $\begin{array}{c}\text { Potential Areas } \\
\text { (has.) }\end{array}$ \\
\hline Zamboanga City & $3,733.90$ & $1,660.00$ \\
\hline Zamboanga Sibugay & $20,520^{*}$ & $9,454.00$ \\
\hline Zamboanga del Sur & $2,183.00$ & $6,037.00$ \\
\hline Zamboanga del Norte & 1,678 & - \\
\hline Total & $\mathbf{2 7 , 8 1 4 . 9 0}$ & $\mathbf{1 7 , 1 5 1 . 0 0}$ \\
\hline
\end{tabular}

Table 1: Seaweed Production Area in Zamboanga Peninsula.

Source: Zamboanga Peninsula Seaweed Industry Cluster (ZIC) Report, March 2014.

*Updated by the provincial Planning \& Development Office thru Multi-Stakeholders Consultation Workshop, 2nd Quarter of 2015, Zamboanga Sibugay.

\section{Specific Job Value Chain}

Below is the specific value chains generated in the survey and FGD in Ipil and Alicia municipalities, Zamboanga Sibugay (Figure 1). Chain 1 started in Ipil, Zamboanga Sibugay and Chain 2 in Alicia, Zamboanga Sibugay. In Chain 1 product flow ends in processor in Zamboanga City while Chain 2 processor is Cebu City. For the purpose of describing and estimating the full time job in the seaweed industry Chain I illustration is used. 
Chain 1: Ipil, Zamboanga Sibugay

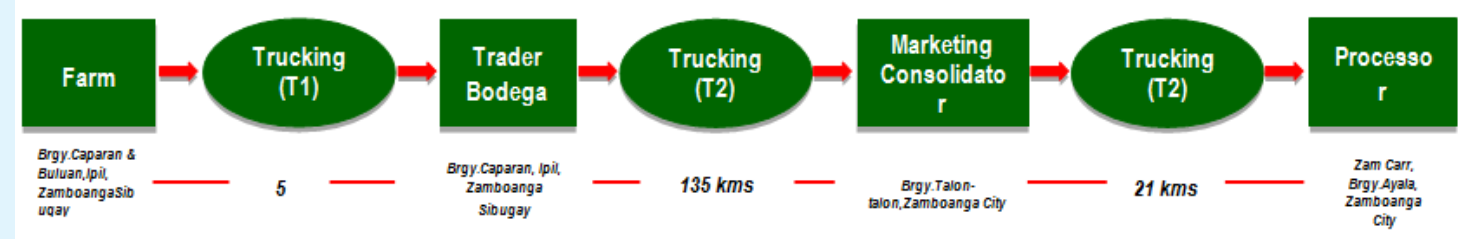

Chain 2: Alicia, Zamboanga Sibugay

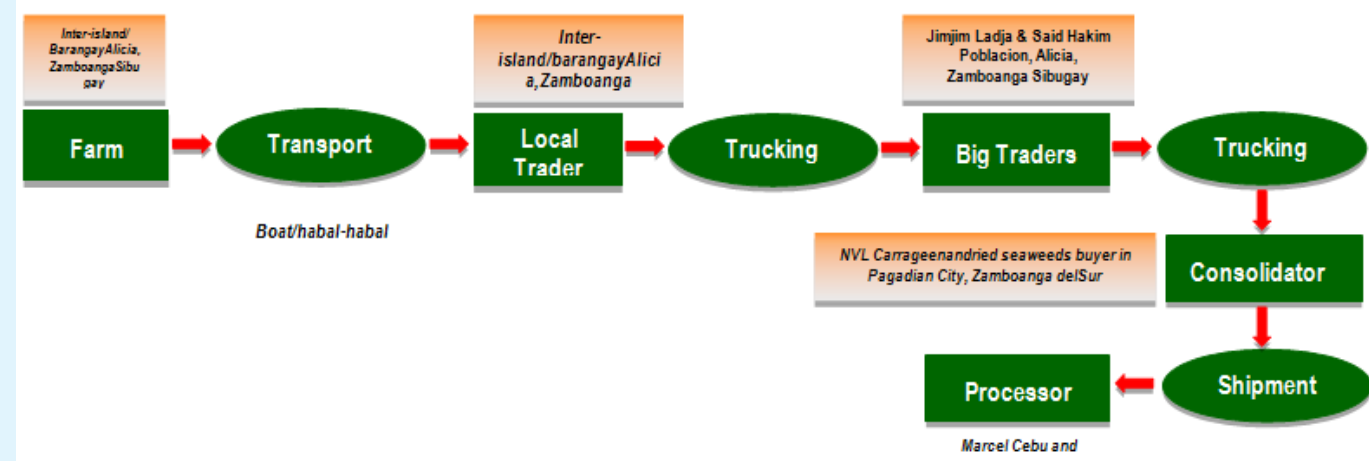

Figure 1: Supply Chains of seaweeds in Zamboanga Sibugay.

\section{Production and Income in Seaweed Farming}

The average production at normal condition is $5,646.5$ kg per $1 / 4$ hectare per cropping from three municipalities of Alicia, Ipil and Tungawan, (3 top producing municipalities) Zamboanga Sibugay. The average production cost of $P 21,239.66$ is too big for the farmer to invest (table 2) .A farmer will spent about P 2.75 per $\mathrm{kg}$ of seaweed. The biggest bulk of the cash cost is supplies including seedlings. The computed net return per farm is P 6,993.00 at the price of P5.00 per kg of fresh seaweeds. The unlikely decrease in the price at present (2016) of $P$ 3.00 per $\mathrm{kg}$ of fresh or P 28.00 per $\mathrm{kg}$ of raw dried seaweeds (RDS) at a ratio of $1 \mathrm{~kg}$ RDS : $7 \mathrm{~kg}$ fresh, would make farmers very difficult to provide the needs of the family. The price of dried seaweeds in 2013 was P 60.00 in the barangay level almost half the price in 2015 at $\mathrm{P}$ $28.00 / \mathrm{kg}$.

\begin{tabular}{|c|c|c|c|c|c|}
\hline \multirow{2}{*}{ ITEM } & \multicolumn{3}{|c|}{ Per Hectare } & \multirow{2}{*}{ PER FARM (P) } & \multirow{2}{*}{$\begin{array}{c}\text { PER KILOGRAM } \\
\text { (P) }\end{array}$} \\
\hline & Quantity & Unit & Value (P) & & \\
\hline Production & 22,586 & $\mathrm{~kg}$ & 112,930 & $28,232.50$ & 5.00 \\
\hline Area harvested & 0.25 & has & & & \\
\hline Number of farms & 30 & & & & \\
\hline Cash Costs & & & 38,360 & 11,643 & 1.70 \\
\hline Seedlings & 2,000 & $\mathrm{~kg}$ & 10,000 & 2,500 & 0.44 \\
\hline Hired Labor & 15 & man-day & 2,250 & 1,500 & 0.10 \\
\hline \multicolumn{6}{|l|}{ Rentals: } \\
\hline Dryer & & & 300 & 300 & 0.01 \\
\hline Boat with engine & & & 250 & 250 & 0.01 \\
\hline Fuel and oil & & & 240 & 240 & 0.01 \\
\hline Transport cost of inputs & & & 30 & 30 & a/ \\
\hline \multicolumn{6}{|l|}{ Supplies: } \\
\hline Anchor bars/ Wooden poles & 200 & pc & 2,000 & 1,000 & 0.09 \\
\hline Floaters & & & 3,500 & 875 & 0.15 \\
\hline Soft tie & 360 & pack & 1,440 & 360 & 0.06 \\
\hline
\end{tabular}




\section{International Journal of Oceanography \& Aquaculture}

\begin{tabular}{|c|c|c|c|c|c|}
\hline Monoline straw & 30 & roll & 9,600 & 2,400 & 0.43 \\
\hline Binder & 30 & roll & 8,250 & $2,062.50$ & 0.37 \\
\hline Repairs/Improvements & & & 500 & 125 & 0.02 \\
\hline Non-Cash Cost & & & $\mathbf{1 0 , 0 0 0}$ & $\mathbf{2 , 5 0 0}$ & $\mathbf{0 . 4 4}$ \\
\hline Seedlings (own produced) & $2,000.00$ & kg & 10,000 & 2,500 & 0.44 \\
\hline Imputed Costs & & & $\mathbf{1 3 , 6 1 6}$ & $\mathbf{7 , 0 9 7 . 1 6}$ & $\mathbf{0 . 6 0}$ \\
\hline Operator labor & 38 & man-day & 6,250 & 4,000 & 0.28 \\
\hline Family labor & 19 & man-day & 2,416 & 1,680 & 0.11 \\
\hline Depreciation & & & 400 & 200 & 0.02 \\
\hline Interest on operating capital & & & 4,550 & $1,217.16$ & 0.2 \\
\hline Total Costs & & & $\mathbf{6 1 , 9 7 6}$ & $\mathbf{2 1 , 2 3 9 . 6 6}$ & $\mathbf{2 . 7 5}$ \\
\hline Gross Returns & & & $\mathbf{1 1 2 , 9 3 0}$ & $\mathbf{2 8 , 2 3 2 . 5 0}$ & $\mathbf{5 . 0 0}$ \\
\hline Returns Above Cash Costs & & & $\mathbf{7 4 , 5 7 0}$ & $\mathbf{1 6 , 5 9 0}$ & $\mathbf{3 . 3 0}$ \\
\hline Returns Above Cash And Non-Cash Costs & & & $\mathbf{6 4 , 5 7 0}$ & $\mathbf{1 4 , 0 9 0}$ & $\mathbf{2 . 8 6}$ \\
\hline Net Returns & & & $\mathbf{5 0 , 9 5 4}$ & $\mathbf{6 , 9 9 3}$ & $\mathbf{2 . 2 5}$ \\
\hline Net Profit-Cost Ratio & & & $\mathbf{0 . 8 2}$ & $\mathbf{0 . 3 3}$ & $\mathbf{0 . 8 2}$ \\
\hline
\end{tabular}

Table 2: Average Cost and Return of Seaweed Production per Hectare in Zamboanga Sibugay, 2015.

a/ Less than 0.01

Source: Production data triangulated from PAO, MAO \& survey results; cost data based on survey results; Price is average from January - June 2015.

Per hectare per cropping.

\section{Current Number and Type of Jobs Available}

Seaweed farming is a family-based enterprise that employs about 5 persons working together with 3 family members. Women and children do menial task of cleaning, tying, drying, and sorting the harvest. During school days about 2-3 hours daily are spent on these activities and 6 hours during weekends and holidays. Although most farmers pay labor after selling the harvest, laborers are still willing to work. The full time job in the entire value chain were computed based on the survey and focus group discussion of seaweed farmers, barangay traders, consolidators, big traders and processor. A total of 0.9757 full time employment (FTE) per hectare is generated in seaweed farm (Table 3). The farming operation average 0.5737 FTE from farm establishment, preparation of cuttings, tying of seedlings, planting, farm maintenance and harvesting. Post- harvest activity entails 0.128 FTE, delivery to big traders/ consolidators' average 0.004 FTE and processing of semi-refined carrageenan and alkali chips at 0.27 FTE. Table 4 presents the FTE of Zamboanga Sibugay based on the job estimation in table 3.Thus the total job created for Zamboanga Peninsula is 28,342 (Table 5).

\begin{tabular}{|c|c|c|}
\hline STAGE & FTE/ha & FTE/MT \\
\hline Farming & 0.5737 & 0.0036 \\
\hline Farm establishment & 0.016 & 0.0001 \\
\hline Preparation / cutting of seedlings & 0.077 & 0.0005 \\
\hline Tying of seedlings & 0.077 & 0.0005 \\
\hline Planting of tied seedlings & 0.038 & 0.0002 \\
\hline Farm maintenance & 0.288 & 0.0018 \\
\hline Harvesting & 0.077 & 0.0013 \\
\hline Postharvest & 0.128 & 0.0003 \\
\hline Delivery of Dried Seaweeds to Consolidator & 0.004 & 0.0017 \\
\hline Processing of Semi-Refined Carrageenan & 0.27 & 0.069 \\
\hline Total Fulltime Employment & 0.9757 & 2.14 \\
\hline Person Days Equivalent & 303.34 & \\
\hline
\end{tabular}

Table 3: Job Estimation, Seaweed Full-Time Employment.

FTE - full-time employment is defined as eight hours of work per day, six days a week. 


\section{International Journal of Oceanography \& Aquaculture}

\begin{tabular}{|c|c|c|c|c|c|c|}
\hline Municipalities & Area Planted* & $\begin{array}{c}\text { FTE Farming } \\
(\mathbf{0 . 5 7 3 7 / h a )}\end{array}$ & $\begin{array}{c}\text { FTE Postharvest } \\
\mathbf{( 0 . 1 2 8 / h a )}\end{array}$ & $\begin{array}{c}\text { FTE Delivery } \\
\mathbf{( 0 . 0 0 4 / h a )}\end{array}$ & $\begin{array}{c}\text { FTE Processing } \\
\mathbf{( 0 . 2 7 / h a )}\end{array}$ & FTE Total \\
\hline Ipil & 3,268 & $1,874.85$ & 418.3 & 13.072 & 882.36 & $3,188.59$ \\
\hline Naga & 1,752 & $1,005.12$ & 224.26 & 7.008 & 473.04 & $1,709.42$ \\
\hline Talusan & 552 & 316.68 & 70.66 & 2.208 & 149.04 & 538.58 \\
\hline Payao & 532 & 317.14 & 68.1 & 2.128 & 143.64 & 531 \\
\hline Tungawan & 3,112 & $1,785.35$ & 398.34 & 12.448 & 840.24 & $3,036.37$ \\
\hline Malangas & 1,216 & 697.62 & 155.65 & 4.864 & 328.32 & $1,186.45$ \\
\hline R.T.Lim & 2,408 & $1,381.47$ & 308.22 & 9.632 & 650.16 & $2,349.49$ \\
\hline Buug & 428 & 245.45 & 54.78 & 1.712 & 115.56 & 417.51 \\
\hline Mabuhay & 716 & 410.77 & 91.65 & 2.864 & 193.32 & 698.6 \\
\hline Alicia & 6,076 & $3,485.80$ & 777.73 & 24.304 & 1640.52 & $5,928.35$ \\
\hline Olutanga & 460 & 263.9 & 58.88 & 1.84 & 124.2 & 448.82 \\
\hline Total & $\mathbf{2 0 , 5 2 0}$ & $\mathbf{1 1 , 7 8 4 . 1 5}$ & $\mathbf{2 , 6 2 6 . 5 6}$ & $\mathbf{8 2 . 0 8}$ & $\mathbf{5 , 5 4 0 . 4 0}$ & $\mathbf{2 0 , 0 3 3 . 1 9}$ \\
\hline
\end{tabular}

Table 4: Estimated number of Jobs in the Seaweed farms in Zamboanga Sibugay, 2015.

Sources: * Office of the Provincial Agriculturist, Ipil, Zamboanga Sibugay

** Computed Full Time Job based from the survey data.

\begin{tabular}{|c|c|c|c|c|c|}
\hline Types of Job & Zambo Sibugay & Zambo City & Zambo del Sur & Zambo del Norte & Zambo Peninsula \\
\hline Farming & 11,728 & 2,134 & 1,247 & 959 & 16,068 \\
\hline Postharvest & 2,613 & 475 & 278 & 213 & 3,579 \\
\hline Delivery & 80 & 15 & 9 & 7 & 111 \\
\hline Processing & 5,525 & 1,005 & 588 & 452 & 7,570 \\
\hline Total FTE & $\mathbf{1 9 , 9 4 6}$ & $\mathbf{3 , 7 4 2}$ & $\mathbf{2 , 9 7 1}$ & $\mathbf{1 , 6 8 3}$ & $\mathbf{2 8 , 3 4 2}$ \\
\hline
\end{tabular}

Table 5: Current Number and Types of Job Created.

\section{Constraints in the Industry}

The severe constraints (in red color) in the seaweeds industry for creating more and better job includes: lack of good quality planting materials to increase productivity or in the context of lack of seedling nurseries in the production areas. When farmers plant at the same time, seedlings are not sufficient, thereby limiting the area to be planted despite the presence of available and suitable area for production. Seedling nurseries were limited and therefore farmers used same varieties repeatedly causing production to diminish. So far there are no research and development efforts undertaken to improve seedling quality and disease control of seaweeds (Figure 2). The constrains in orange is moderate and yellow is minor while green means no constraints.
Another equally important constraint is the lack of ready access to credit for farmers to avail for outright payment of inputs and farm structures particularly for deep sea farming. The production cost of P 21,239.66 for $1 / 4$ hectare for near shore farming is too big for them to invest. Due to absence of available credit facility, farmers get advance payment from local traders to provide family subsistence needs and production needs. This arrangement is prevailing in the provinces and farmers' buying price is dictated by the local traders. The cost of production for deep sea farming is higher compared to near shore due to the requirement of anchor bars or wooden post. The moderate constraints (in orange color) are also important to be considered to address the problems of the industry. Likewise, the minor constraints are in yellow and green has no constraints. Those in white colors mean no information. 


\section{International Journal of Oceanography \& Aquaculture}

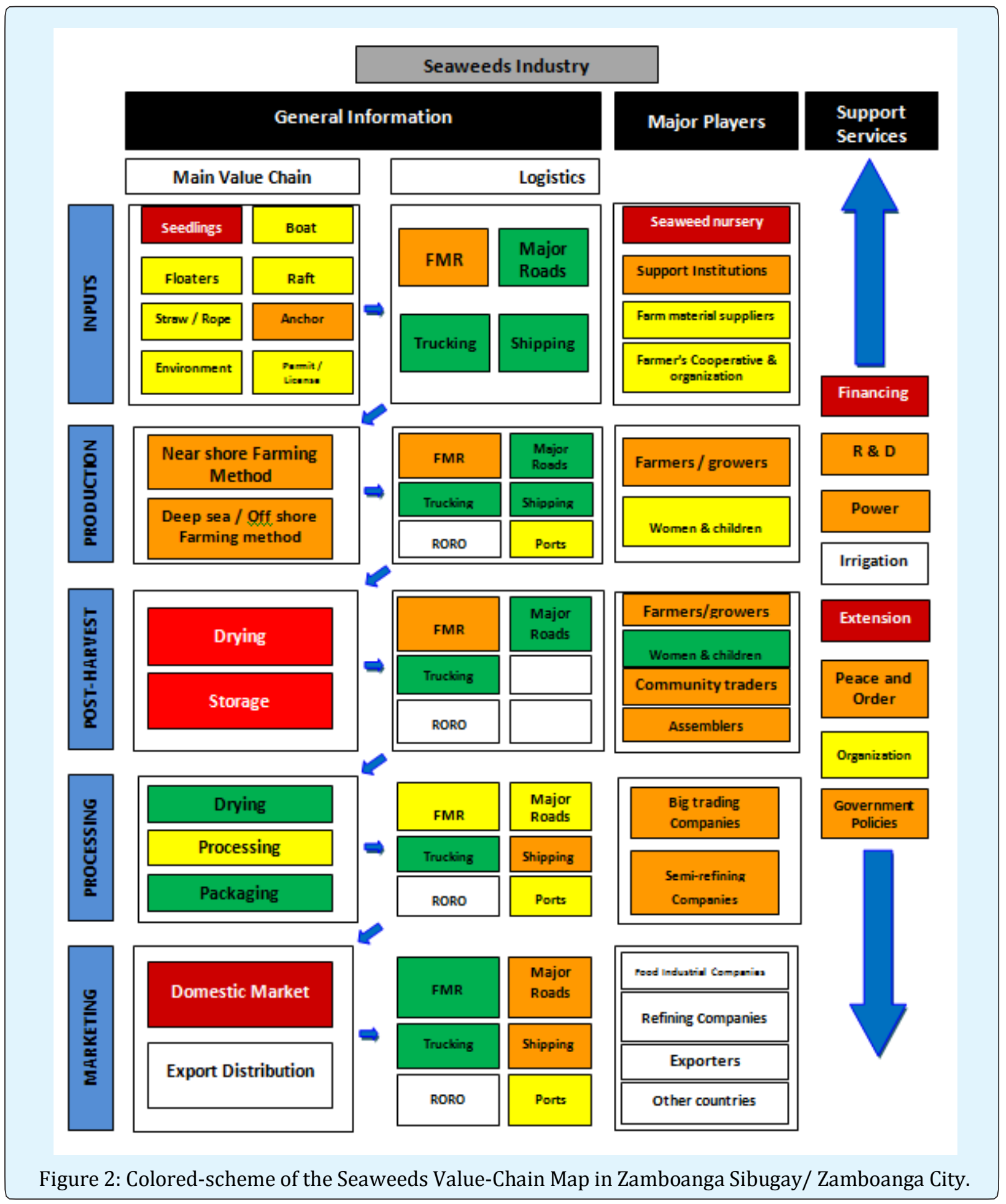

Post- harvest management poses major challenges to both farmers and traders due to poor post- harvest facilities such as drying and storage areas. In the absence of stilt drying area, farmers dry seaweeds on grounds using coconut midribs or fish nets resulting in dirty RDS.
Local traders also lack clean drying and storage facilities. To shorten drying period, traders and farmers practice application of salt which ultimately affects quality. Other farmers mixed foreign matters to increase weight. This condition contaminates RDS resulting to low quality and 


\section{International Journal of Oceanography \& Aquaculture}

price of the product. In some remote barangays, farm to market road are poor resulting to high overhead cost and affecting income of farmers.

In the entire Zamboanga Sibugay province, coastal municipalities were provided with 59 concrete stilt dryers through the Local Development Fund. However, 37 were non- operational and the remaining 22 functional units have no guarantee of sustainability if not properly maintained by the users themselves.

The lack of realistic extension services on proper seaweed production technology to produce quality seaweed products also poses threat to achieve competitiveness in the world market. This is due to the lack of trainings of farmers and traders in post- harvest processing to conform to quality standards. If there were trainings provided, there were no monitoring and evaluation schemes to validate if trainings provided were appropriately applied by farmers. Likewise, there is lack of Information Education Communication in the production and post- production technology, lack of knowledge and skills in producing alternative value adding seaweed products at the village level.

The unregulated price of seaweeds has affected farmers in Zamboanga Sibugay due to the presence of cartel who dictates buying price. Cartel threatens the growth of the industry as farmers are at the mercy of the big traders and processors. The situation is compounded as processors cited the low quality of RDS as a result of contamination. Likewise, the very low price of raw seaweeds affects domestic trading due to smuggling of seaweeds (without tax) from Indonesia and Malaysia sold at a lower price and the offer for 90 days credit. The scenario of high production and marketing cost of farmers resulting to low income discourage some farmers to continue planting, while others reduce the area of production. Furthermore, only two processing plants are present in Zamboanga Peninsula. Investors are disinterested to put up processing plants in the provinces due to volatile peace and order situation. Summary of the constraints are presented in tables $6 \& 7$.

\begin{tabular}{|c|c|}
\hline \multicolumn{2}{|r|}{ Severe Constraints } \\
\hline \multirow{4}{*}{ Seedlings / Seedling Nursery } & - Shortage of quality planting materials, seedling nursery is very limited. \\
\hline & - Lack of support in establishing seedlings nurseries in seaweed producing areas \\
\hline & $\begin{array}{l}\text { - Farmer's raise their own seedlings and practice propagation of same cultivars more } \\
\text { than three times resulting to low productivity }\end{array}$ \\
\hline & $\begin{array}{c}\text { - Lack of research and development efforts in improving seedling of high yielding quality, } \\
\text { climate change and disease resistant varieties }\end{array}$ \\
\hline \multirow{4}{*}{ Financing/ Financial Services } & $\begin{array}{c}\text { - Lack of initial capital for outright payment for seedlings and farm implements. Despite } \\
\text { available area, farmer's average farm size is } 1 / 4 \text { ha. Average cost is almost P20, } 000 \text { for } 1 / 4 \\
\text { ha. Others have even smaller areas depending on financial capability. }\end{array}$ \\
\hline & $\begin{array}{c}\text { - In some areas in Zamboanga Sibugay traders extended financing to only P5,000 per } \\
\text { farmer, lower than the required production cost excluding the subsistence cost for the } \\
\text { family while waiting for the harvest. }\end{array}$ \\
\hline & $\begin{array}{c}\text { - Employment or labor requirement is limited to } 5 \text { persons per } 1 / 4 \text { ha including operator } \\
\text { and his family. Payment of labor is made after selling the seaweeds } \\
\end{array}$ \\
\hline & - Farmers harvest seaweeds pre-maturely because of the need for cash \\
\hline \multirow{5}{*}{$\begin{array}{l}\text { Poor post-harvest facilities and } \\
\text { farm to market road }\end{array}$} & $\begin{array}{c}\text { - Inadequate support for farm village post- harvest and drying facilities for both farmers } \\
\text { and traders which resulted to poor quality seaweeds. } \\
\end{array}$ \\
\hline & $\begin{array}{l}\text { - Stilt dryer or concrete pavement is very limited in the farmers' level. About } 60 \% \text { of the } \\
\text { farmers sell fresh/ wet seaweeds due to the absence of drying facilities. Likewise sun } \\
\text { drying is dependent on weather condition. Selling RDS will give farmer better income } \\
\text { than wet seaweeds. }\end{array}$ \\
\hline & $\begin{array}{c}\text { - Farmers practice adulteration of RDS (addition of salt to preserve and add weight to the } \\
\text { product) and buying price do not differ }\end{array}$ \\
\hline & $\begin{array}{l}\text { - In areas where communal dryer facilities were provided from Local Development Fund } \\
\text { of LGUs, there are no existing guidelines in the proper management of the facilities. Two } \\
\text { out of three were already non- operational. }\end{array}$ \\
\hline & \begin{tabular}{|l|} 
There are barangays with difficult FRM during heavy rains resulting to high overhead \\
\end{tabular} \\
\hline
\end{tabular}

Teresita A Narvaez. Seaweeds Jobs Value-Chain Analysis in Zamboanga Peninsula, Philippines, 2015. Int J Oceanogr Aquac 2018, 2(2): 000136. 


\section{International Journal of Oceanography \& Aquaculture}

\begin{tabular}{|c|c|}
\hline & cost \\
\hline \multirow{5}{*}{$\begin{array}{l}\text { Extension services/ Farmers } \\
\text { Knowledge }\end{array}$} & $\begin{array}{l}\text { Farmers lack appropriate knowledge in the enterprise resulting to detrimental practices } \\
\text { that cause low productivity; lack of know how to cope with effects of climate change and } \\
\text { attack of "ice-ice" disease }\end{array}$ \\
\hline & $\begin{array}{l}\text { - Lack of trainings for farmers and traders to capacitate them on post- harvest processing } \\
\text { to conform to quality standards }\end{array}$ \\
\hline & - Lack of extension program for disease mitigation \\
\hline & $\begin{array}{l}\text { Little access/availability of free training on seaweed farming and management. Farmers } \\
\text { engage in seaweed farming even if they lack the technical knowledge just because they } \\
\text { learn that other farmers were successful }\end{array}$ \\
\hline & $\begin{array}{l}\text { - Lack of knowledge and skills in producing alternative value adding products from } \\
\text { seaweeds at the village level to increase income of farmers }\end{array}$ \\
\hline \multirow{2}{*}{$\begin{array}{l}\text { Domestic Market / Price } \\
\text { monopoly }\end{array}$} & $\begin{array}{c}\text { - Very low price of raw seaweeds affects domestic trading due to smuggling of seaweeds } \\
\text { (without tax) from Indonesia and Malaysia. }\end{array}$ \\
\hline & eting cost and low revenues discourage farmers to plant. \\
\hline
\end{tabular}

Table 6: Severe constraints in the Jobs Value Chain Mapping.

\begin{tabular}{|c|c|}
\hline \multicolumn{2}{|r|}{ Moderate Constraints } \\
\hline Input: Anchor & $\begin{array}{l}\text { High cost of Iron bars used as anchor for the seaweed plants in deep sea farming which gives } \\
\text { higher yield, resistant to pathogenic infections due to cooler temperature, and resilient to } \\
\text { strong waves and current. }\end{array}$ \\
\hline $\begin{array}{l}\text { Production sites : Near } \\
\text { shore and Deep sea }\end{array}$ & $\begin{array}{l}\text { - Production is hampered by environmental factors beyond the control of farmers coupled } \\
\text { with the lack of knowledge of farmers to mitigate the effect of climate change and disease } \\
\text { attacked }\end{array}$ \\
\hline Farm to Market Road & $\begin{array}{l}\text { - Some areas in the provinces still needs concreting of roads which are non-passable during } \\
\text { rainy seasons. In Alicia municipality, about } 133 \mathrm{kms} \text { are bad roads. }\end{array}$ \\
\hline \multirow{2}{*}{ Shipping Lines } & - Shortage and limited trips for cargo \\
\hline & - Products are reroute to Davao City for exportation through land transport \\
\hline \multirow{2}{*}{ Support Institutions } & $\begin{array}{l}\text { - Lack of community-based system to monitor sea and weather conditions in relation to } \\
\text { seaweed farming }\end{array}$ \\
\hline & - Lack of weather index based insurance for seaweed farming \\
\hline \multirow{2}{*}{$\begin{array}{c}\text { Farmers/growers } \\
\text { Community traders } \\
\text { /Assemblers }\end{array}$} & - Malpractices activities such as adulteration (or addition of salt on RDS) to add weight. \\
\hline & $\begin{array}{c}\text { - Unfavorable trade practices and inconsistent pricing resulting to poor market of seaweed } \\
\text { products. }\end{array}$ \\
\hline \multirow{2}{*}{$\begin{array}{c}\text { Big Traders / Semi-refining } \\
\text { companies }\end{array}$} & - Inconsistent buying price to farmers or small/local traders. \\
\hline & - No price bulletin or bases of low buying price. \\
\hline \multirow[t]{2}{*}{ Peace and Order } & $\begin{array}{l}\text { - Unstable peace and order situation specifically in Zamboanga Peninsula resulted to } \\
\text { abandonment of farm areas during conflict situations. }\end{array}$ \\
\hline & $\bullet$ Incidence of stealing of seaweeds in the growing area \\
\hline \multirow{4}{*}{ Government Policies } & $\begin{array}{c}\text { - Lack of updated seaweed zoning supported with conduct of scientific site suitability } \\
\text { assessment. }\end{array}$ \\
\hline & $\begin{array}{c}\text { - Strengthen the implementation of the establishment of the Regional Seaweed Coordinating } \\
\text { Unit (RSCU) for monitoring and evaluation (BFAR) } \\
\end{array}$ \\
\hline & - Elimination of cartel in buying and red tapes that affected small farmers \\
\hline & $\begin{array}{c}\begin{array}{c}\text { Implementation of common standard quality assurance that will monitor quality of products } \\
\text { from the farmers level to the traders. }\end{array} \\
\end{array}$ \\
\hline
\end{tabular}

Table 7: Moderate constraints in the Jobs Value Chain Mapping.

Teresita A Narvaez. Seaweeds Jobs Value-Chain Analysis in Zamboanga Peninsula, Philippines, 2015. Int J Oceanogr Aquac 2018, 2(2): 000136. 


\section{International Journal of Oceanography \& Aquaculture}

\section{Conclusions}

Seaweeds farming is one of the main employment of coastal dwellers in the region whose livelihood is dependent on marine resources, particularly the minority and marginalized households. About $90 \%$ are engaged in farming of $1 / 4$ hectare with an average production of $5,646.5 \mathrm{~kg}$ per $1 / 4$ hectare per cropping at normal condition. However, the average production cost of $\mathrm{P}$ $21,239.66$ is too big for the farmer to invest. A farmer will spent about P 2.75 per kg of seaweed. The biggest bulk of the cash cost is supplies including seedlings. The computed net return per farm is $\mathrm{P} 6,993.00$ at the price of P5.00 per kg of fresh seaweeds. Hence, any decrease in the price would result to a lesser income for their family.

Seaweed farming is a family-based enterprise that employs about 5 persons working together with 3 family members. Women and children do menial task of cleaning, tying, drying, and sorting the harvest. During school days about 2-3 hours daily are spent on these activities and 6 hours during weekends and holidays.

A total of 0.9757 full time employments (FTE) per hectare is generated in seaweed farm. The farming operation average 0.5737 FTE from farm establishment, preparation of cuttings, tying of seedlings, planting, farm maintenance and harvesting. Post- harvest activity entails 0.128 FTE, delivery to big traders/ consolidators' average 0.004 FTE and processing of semi-refined carrageenan and alkali chips at 0.27 FTE. The total FTE in seaweed industry for the entire region is 28,342 for the total area planted to seaweeds of $27,814.90$ hectares. However, there are still potential area suitable for the production of seaweeds recorded at 17,151.00 hectares. This would mean an increase in full time employment if the constraints will be properly addressed.

The reasons for the declining performance of the industry is the low quality of raw dried seaweeds due to the severe constraints cited above. The only hope for our seaweed farmers to earn more is to provide solution to the lack of quality seedling for planting, provision of postharvest facilities that will improve quality of raw dried seaweeds, support for financing and marketing price of raw dried seaweeds.

\section{Recommendation to Address the Constraints}

To fully address the major constraints for additional job creation in the seaweed industry, effort shall be geared toward establishment of seaweed gene bank and nurseries to be under the supervision of BFAR and LGUs but under the management of farmers' associations in the provinces where different seaweed varieties can be cultured. This will serve as viable sources of quality planting materials suited for the area and farming systems adopted by the farmers, thereby increasing production area and employment opportunities. Existing nurseries established by selected farmers through the programs initiated by BFAR needs to be evaluated, strengthened and enhanced.

Likewise, to sustain the needs for planting materials, research and development program must be undertaken to generate disease and climate change resistant varieties. This concern can be properly handled by research institutions in the region particularly the academe in collaboration with Department of Science and Technology and Bureau of Fishery and Aquatic Resources. Three strong research institutions in the region are capable of engaging in this commodity: Western Mindanao State University (WMSU) - Biology Department of the College of Science and Mathematics; Zamboanga State College of Marine Sciences and Technology (ZSCMST); and Jose Rizal Memorial State University (JRMSU) Dapitan City Campus.

In addition, there is a need to engage in the development of food and non-food high-value added products from seaweeds through research in these institutions as additional opportunities of farmers in generating income from seaweeds. Ultimately, employment can be generated as the result of establishing social enterprises and cottage industries for food and non-food high value products.

Another critical concern is the provision of existing financing windows for small and marginalized group- the farmers, who are the less privilege and easily manipulated by traders. The availability of financing can open the doors for increase number of farmers in the industry as well as increase production area. Added to this is the opportunity of crop assistance and insurance programs in the event of crop failure due to fortuitous events. The main reason for farmers to lose interest in engaging the enterprise after crop failure is the absence of strong government support and policies to benefit the farmers. This means presence of inter-agency interventions to provide basic social services, financing, facilities and other productive resources to increase their capacity to engage in the industry. For instance, the microfinance schemes that have proved successful in other countries like Bangladesh and India seaweed growers may provide 


\section{International Journal of Oceanography \& Aquaculture}

viable means for dependent farmers to break free from disadvantageous arrangements with traders.

One specific intervention is the provision of effective extension program to capacitate farmers in the production and marketing system. This includes production technology on the knowledge and skills in determining water salinity, temperature and other climatic conditions as well as the choice of appropriate seaweed varieties and farming systems are contributory to high production in the area. However, it is important to implement monitoring scheme to make sure that trainings provided were properly applied. This is also a way of checking if recipient of the BFAR's program of free planting materials and other inputs are truly seaweed farmers. Likewise, market price information is vital for farmers in making decisions as regard to production and marketing systems. For instance decision whether to sell fresh or dried from gives farmer the highest return.

Another important intervention is the establishment of standard policy for quality assurance. The common conflict of traders and farmers is the determination of moisture content of raw dried seaweeds (RDS) as basis for pricing. The lower the moisture content, the higher is the price. The presence of contaminants (sand, soil and other foreign matters) as well as adulterated RDS (application of salt) also affects pricing and quality. Processors claimed that one of the problems encountered in processing is the breakdown of machines caused by clogging of plastic straws and other foreign matters incorporated in the RDS. A strong government policy is required in banning contaminated and adulterated products in the market to control production of low quality RDS and consequently establish good market price of the product.

To realize the goal of quality RDS, the intervention needed is the provision of government assisted processing facilities particularly additional stilt dryers, moisture content detector and clean storage areas free from contaminations. Sad to note that many of the processing facilities acquired through the Local Development Fund of LGUs were non-functional due to misuse of concern users in the area. This requires guidelines and policies on the proper use and the acceptance of responsibility through farmers' association.

The last recommendation is the establishments of social enterprises or cottage industries through inter agency collaboration on value addition of seaweed products at the village level to generate higher income and to provide more opportunities in the use of seaweeds as raw materials for home consumption and thereby generating more employment. By products of seaweeds are already introduce in the market such as crackers, chippy, polvoron, candies, biscuits and jam. Likewise, there is a strong desire for farmers to put up a village type carrageenan processing plant to be supervised by intergovernment agencies and partly owned by federations of farmers association in the province.

\section{Estimating Job Impact in Zamboanga Peninsula Region}

The entire Zamboanga Peninsula region can generate additional FTE of 12,119.91 if all conditions are present particularly quality seedlings and other important inputs, financing, technology and appropriate trainings of farmers. Thus, the current FTE of 18,077.88 can increase to $12,119.91$ (Table 5) based on additional potential area for seaweed farming determined by Bureau of Fishery and Aquatic Resources -region 9 (BFAR-9). However, additional FTE can be generated if processing for value addition will be undertaken by the farmers' association in the area.

\begin{tabular}{|c|c|c|c|c|c|c|}
\hline Location & $\begin{array}{c}\text { Area Planted } \\
\mathbf{( 1 )}\end{array}$ & FTE/ha (2) & $\begin{array}{c}\text { Total Current } \\
\text { FTE (3) (1 x 2) }\end{array}$ & $\begin{array}{c}\text { Potential Area Potential Jobs (5) } \\
\mathbf{( 4 )}\end{array}$ & $\begin{array}{c}\text { Total Full Time } \\
\text { Employment (6) } \\
\mathbf{( 3 + 5 )}\end{array}$ \\
\hline $\begin{array}{c}\text { Zamboanga } \\
\text { Sibugay }\end{array}$ & $20,520.00$ & 0.643 & $13,194.36$ & $9,454.00$ & $6,078.92$ & $19,273.28$ \\
\hline Zamboanga City & $3,733.90$ & 0.643 & $2,400.90$ & $1,660.00$ & $1,067.38$ & $3,468.28$ \\
\hline Zamboanga Sur & $2,183.00$ & 0.643 & $1,403.67$ & $6,037.00$ & $3,881.79$ & $5,285.46$ \\
\hline Zamboanga Norte & $1,678.00$ & 0.643 & $1,078.95$ & $1,698.00$ & $1,091.81$ & $2,170.77$ \\
\hline TOTAL & $28,114.90$ & & $18,077.88$ & $18,849.00$ & $12,119.91$ & $30,197.79$ \\
\hline
\end{tabular}

Table 8: Summary of Job Impact in Zamboanga Peninsula Region. 


\section{International Journal of Oceanography \& Aquaculture}

\section{Risks and Mitigation Measures, Including Environmental Impact}

\section{Increasing Influx of Raw Dried Seaweeds from Malaysia and Indonesia}

The continuous and increasing importation of RDS from Malaysia and Indonesia to the Philippines pose threat to our local seaweed farmers. The importation of RDS (without tax) causes the local price of seaweed to go down bringing the price level below break-even cost of farmers. Government policies must protect our small farmers in the seaweed industry by imposing strict policies for importation.

\section{Climate Change}

Seaweeds farming are highly vulnerable to climate change. Extreme hot and cold temperature caused the growth of ice-ice and other diseases. Farmers need sufficient knowledge on how to mitigate the effects of climate change. BFAR and other technical experts must capacitate farmers in adopting measures to combat the effects of climate change. Furthermore, research studies must be undertaken to produce seaweed strains that can withstand climate change.

\section{Peace and Order Condition}

The armed conflict between government troupes and the rebels consisting of MNLF, MILF and Abbu Sayap groups continue to create disturbances. During the September Zambo Seiges in 2013, 70\% of the growing seaweeds in affected areas were destroyed and stolen. Farmers with their families left the area and transferred to other provinces. The Bangsamoro Basic Law (BBL) is another important issue that may affect the seaweed industry in the region. An exhaustive consultation with the affected sector, specifically the aquaculture sector, has to be ensured in such a way that a feasible win-win compromise will be attained.

\section{Natural Calamities}

The occurrence of natural disasters will likewise interrupt the operation of the seaweed industry. Seaweeds being raised in the coastal waters are very vulnerable to changes in temperature caused by drought, flooding and other disasters. The Zamboanga Peninsula region is vulnerable to seasonal flooding, drought and earthquake (http://zamboanga.net/sepvol1chap1.htm). Being close to the Cotabato trench, strong earthquakes can hit the city and nearby provinces which can result in tsunamis particularly that of the eastern coastal areas.

\section{Property Rights}

LGUs ordinance of regulating the area of seaweed farming per farmer of $1 / 4$ hectare at P 50.00 / area will not be implemented due to political reason of the leadership, chances are that those who can afford to invest seaweeds are given the opportunity to earn while those without ready capital for investment will not be deprived of the opportunity. Inasmuch as the area is natural resources, government must be strict in implementing guidelines to benefit the majority of the people.

\section{References}

1. (2013) Bureau of Agricultural Statistics. Seaweed Situation Report 2001-2005. Retrieved from www.bas.gov.ph/

2. (2014) Bureau of Agricultural Statistics. Seaweed Situation Report. Retrieved from http://www.bas.gov.ph/

3. Hayashi L (2013) Eucheumoid algae.

4. Narvaez T (2014) Impact Assessment of Seedstock Improvement of Kappaphycus, Eucheuma and Glacilaria in Zamboanga City and Tawi-Tawi. Western Mindanao State University. Philippine Council for Agriculture, Aquatic and Natural Resources Research and Development.

5. (2014) Zamboanga Seaweed Industry Cluster Report.

6. (2012) Department of Trade and Industry. Value Chain Upgrading Program for Raw Dried Seaweeds in Zamboanga Peninsula.

7. Narvaez T, Echem R, Cornelio N (2014) Value Chain Analysis of Seaweeds in Zamboanga Peninsula. Western Mindanao State University. Philippine Agriculture and Resources Research Foundation, Inc. (PARRFI), International Center for Living Aquatic Resources Management (ICLARM). 